\title{
ACCESS TO FINANCE - STREET VENDORS' DILEMMA IN TWO TOWNS OF SOUTH INDIA
}

\author{
A.R. Sindhu ${ }^{1}$, Vijaya Somasundaram ${ }^{2}$ and A. Mohamed Syed $\mathrm{Ali}^{3}$ \\ ${ }^{1}$ Research Scholar, Department of Management Studies, M. S University, Tirunelveli, \\ India \\ ${ }^{2}$ Assistant Professor, Department of Management Studies, Rajalakshmi Engineering \\ College, Chennai, India \\ ${ }^{3}$ Associate Research Analyst, Nasdaq Corporate Solutions (India) Pvt.Ltd. Nagercoil, \\ India
}

\begin{abstract}
Street Vendors and hawkers constitute entrepreneurial efforts at a micro level in the informal sector. This study attempts to explore the access to sources of finance in the informal sector of street vending in the two towns of South India, Tirunelveli and Nagercoil. A sample of 50 vendors in Tirunelveli and Nagercoil cities was analysed with respect to their initial capital requirements, sources of finance and daily working capital requirements. Concurrently the study also sought to identify the street vendors, awareness of licensing requirement, existence of micro finance opportunities and access to the same. Findings showed that a majority of the street vendors utilized their daily earnings. None of them had any awareness of micro finance and the opportunities arising thereof. The study is significant in terms of revealing the financial needs of the informal sector in tier three cities in South India. The study recommends awareness programs or drives targeted at these informal entrepreneurs to sustain their micro entrepreneurial efforts.
\end{abstract}

\section{KEYWORDS}

Street Vendors, Micro Finance, Street Vending, Entrepreneurs

\section{INTRODUCTION}

Street vending makes vital contribution to the urban and semi urban economies by providing easy access to products or services at affordable prices. Their service is superior for a resident that is on the move which is one of the main reasons why street vendors are found clustered in and around bus stands and railway stations. Over $25 \%$ of workers globally operate in the informal sector. As a nation develops the population increasingly shifts from agricultural activities towards manufacturing and white collar occupations. There is therefore a constant influx of people from the rural to the urban areas. The pressures on the formal employment sectors are high and inevitably a lacuna develops that is bridged by the forces of the informal sectors. It is estimated that $30 \%$ to $80 \%$ of the workforce in the urban regions of the developing world are engaged in the informal sector. The increasing urban population with limited income to meet its basic need generates considerable demand for low priced products and services that is supplied by this informal sector street vending or hawking plays a crucial role in alleviating the pressures of unemployment by generating employment albeit informally in the urban and semi urban areas of the Indian subcontinent and contributing towards 50\% of the country's savings and $63 \%$ of the GDP (Sekar, 2008). According to the National policy for metropolitan Street Vendors, 2009, street vendors make up $2 \%$ of the population in the majority cities in India.

DOI : 10.5121/ijmpict.2015.6402 
International Journal of Managing Public Sector Information and Communication Technologies (IJMPICT), Vol. 6, No. 4, December 2015

As division of the familiar area street vendors are from the strictures and norms of the official part, namely taxes and overheads. However their functioning is severely impeded by the constant threat of eviction, demolition, harassment by authorities including the police, lack of legal protection, insurance benefits and lacking the efficiency of capital use (Destombes, 2010). The Tamilnadu State Government has so far to codify and employ the recommendations of the 2009 National Strategy of street vendors (Srinivasan, 2012). Two commissions, the Kanagaraj Commission and its follow up, Justice Ramamurthy Committee have been group to come across the issue. The recommendations of these commissions themselves await implementation. Statistics on street vendors in Tamilnadu seems to be lacking compared to other states owing to the lack of state government initiative. While some information about street vendors in Chennai and Trichy is forthcoming via newspaper articles and research reports, southern parts of Tamilnadu are largely ignored.

In view of above scenario, the researchers decided to do a small survey of street vendors in Tirunelveli and Nagercoil towns. These towns were chosen purely due to the convenience and accessibility for the researchers.

\section{DEFINITION OF STREET VENDORS}

Street Vendors have been defined to comprise any individual engaged in selling of articles, goods, food etc or contributing services to the common society in a street lane, side walk, footpath, pavement, public parks or any other public or private area. It includes hawkers, peddlers and squatters (National Policy for Urban Street Vendors, 2009).

\section{REVIEW OF LITERATURE 3.1 Brief Review of Studies on Street Vendors at the International Level}

Moyano Diaz, Emilio and Castillo Duevara (2008), Informal Work: Motives, Well Being, Health and Happiness in Street Vendors, in this study relationships among work, subjective well being (SWB), Happiness and Health is complex and have a high theoretical and empirical relevance. In this study, these relationships are analysed in street vendors. By means of study and photographs in the five greater cities in Maule Region (Chile), 1556 trade points were found and 258 of them were randomly selected for this study. Results: vendors have a moderated living fulfilment, with lesser satisfaction levels about their associates and leisure time than about their employment and family unit.

Yandi A. Yatmo (2009), Perception of Street Vendors as 'out of place' Urban Elements at Day Time and Night Time. This study attempts to be aware of the public assessment in the direction of elements that subsist inside the chronological dynamics of the cities. Above all the study explores the scope to which street vendors in Jakarta are evaluated as 'out of place' elements at day time and night time. The result recommends that the users' valuation of street vendors as 'out of place' vary from day time to night time. The change of users' estimation also varies across different metropolitan places. Such information concerning the dynamic of 'out of place' appraisal becomes significant in making the conclusion about short-term urban elements in the city.

Alexandre de Padua Carrieri, Invana Benevides Dutra Murta (2011), "Cleaning up the City: A Study on the Removal of Street Vendors from Downtown Belo Horizonte, Brazil", this article presents a important investigation of the replacement of street peddlers in Belo Horizonte, Brazil to the shopping accepted interior markets of the metropolis. In its effort to "clean up" downtown through such replacement, city commission affected the termination of the unofficial work of the city's peddlers and toreros and improved the instability of the political and public environment 
International Journal of Managing Public Sector Information and Communication Technologies (IJMPICT), Vol. 6, No. 4, December 2015

these vendors face at work and perform a site visit and gathered information using discourse analysis, interviews, and desk research.

As per the study conducted by Miriam Otoo, Germaine Ibro, Joan Fulton and James LowenbergDeboer under the title 'Micro-Entrepreneurship in Niger: Factors Affecting the success of women Street Food Vendors (2012)', the authors observe trade accomplishment factors for microentrepreneurs involved in the making and sale of street foods in Niger, drawing on the resourcebased analysis theory. Business achievement was measured by size of firm and vendor's perception of enterprise growth. Their results point out that trading knowledge is a key success factor, while the need for money is a restriction for business success.

\subsection{Brief Review of Studies on Street Vendors at the National Level}

Debdulal Saha (2010) 'Collective Bargaining for Street Vendors in Mumbai: Toward Promotion of Social Dialogue'. This study attempted to understand the role of the collective bargaining process in promoting social dialogue among the street vendors in Mumbai. The International Labour Organization (ILO) has recognized the importance of collective bargaining and the promotion of social dialogue to meet the common demands of workers and so has included the collective bargaining process in its decent work agenda. This study revealed that the rate of unionization among vendors in Mumbai is low. Further, several membership-based organizations are working actively toward the provision of social security for vendors in addition to the provision of formal credit through a co-operative credit society. These organizations are most active in securing the vendor's rights to public space utilization. Thus they promote the social dialogue process by mobilizing the vendors toward realizing their rights at work.

Debdulal Saha (2011), 'Working Life of Street Vendors in Mumbai', this paper portrays the 'working life' of street vendors in Mumbai. The working life of vendors is describe in terms of their economic conditions and the scope of indebtedness, the amount of bribe they have to give in order to sustain themselves in the bazaar, their working hours, the issue of municipal space use and the officially permitted aspect of their activity. The study is tentative in nature and their situations have been explained with the help of both quantitative and qualitative paradigms. The revision illustrate that the street vendors have a loan from moneylenders not merely for their economic activity but also for societal security purpose at a very high rate of interest, which, in turn, lead them to drop into a lock in situation. Hence, the existing working hours of the vendors and the safety conditions in their place of work, together with extensive rent-seeking by local authorities, contribute to a deteriorating working location as well as economic insufficiency for street vendors.

The study on "Will Capacity Building Training Interventions Given to Street Food Vendors Give as Safer Food? : A cross-sectional Study from India" by Manisha Choudhury (2011) observed that, successful food hygiene training and the assent of safe food management practice learn during training are key elements in the control of food-borne illness throughout the world. Using a cross-sectional review plan a trial of 80 street food vendors were selected and provide with training to calculate the existing Knowledge, Attitude and Practice (KAP) concerning food safety and hygiene and the change of the similar after training intervention.

\section{METHODOLOGY}

Analytical survey method was used in this study of street vendors in Tirunelveli and Nagercoil towns. 
International Journal of Managing Public Sector Information and Communication Technologies (IJMPICT), Vol. 6, No. 4, December 2015

\subsection{Population}

All street vendors in Tirunelveli and Nagercoil towns form the population of this study. There is a lack of official figures of street vendor populations in Tirunelveli and Nagercoil. The ministry of Urban Development report states that street vendors form $2 \%$ of the general population in most Indian towns. Based on this estimate it is assumed that the population street vendors in Tirunelveli will be approximately 7000 and in Nagercoil it will be approximately 3000 .

\subsection{Sample}

The researchers used convenience sampling method proportionate to the population to select 34 samples from Tirunelveli and 16 samples from Nagercoil town giving a total of 50 samples.

\subsection{Tool}

A comprehensive questionnaire consisting of 45 questions was prepared. The questions were aimed at securing quantitative data with respect to demographic details, access to finance, daily earnings, re-investment in the trade, awareness of micro finance opportunities, vendor associations and predisposition towards formalization of trade.

\subsection{Data collection Method}

The researchers observed and noted the different points in the two towns of Tirunelveli and Nagercoil where street vendors operated on a daily basis. It was noted that bus stands and railway stations were the most preferred places for vending. The researchers approached the vendors with the questionnaires. Vendors were selected based on their eagerness to take part in the revision. The questionnaire was administered to the vendors at their retailing spot after inform them the intention of the interview and assurance of secrecy. All the vendors who constituted the study sample were curious, eager and enthusiastic to answer the questions.

\section{RESULTS AND DISCUSSIONS}

\subsection{Descriptive statistics revealed the following:}

- The age of the sample varied widely from 23 to 80 years. The majority consisted of mostly early middle aged individuals with a mean age of 46 years

- There were 40 male vendors and 10 female vendors. This figure is higher than those found in a survey of street vendors conducted in ten cities in India by the Tata Institute of Social Sciences (Bhowmik and Debdulal, 2012). The survey originate that female street vendors in most of the cities in India comprise only $2 \%$ of the street vendor population

- Majority of the sample were married (90\%), had a nuclear family structure (74\%) and reasonably small family with two or three kids (70\%)

- The majority of the vendors were either illiterate or had attended only primary school up to 5 or $8^{\text {th }}$ class $(72 \%)$ and most of them sell mainly perishable goods $(70 \%)$ with more than 10 years experience in the trade $(74 \%)$

- For initial investment in the commerce $40 \%$ of the vendors used their personal savings while $38 \%$ lent from money lenders. The remaining sought financial support from parents or spouse

- The street vendors in the sample ranged from vendors of fruits, vegetables, flowers, juice, tender coconut, sweets and savouries, tea/coffee stalls, ironing and watch repairing

- For most of the street vendors in the sample (74\%) there was no seasonal variations in the business 
International Journal of Managing Public Sector Information and Communication Technologies (IJMPICT), Vol. 6, No. 4, December 2015

- The mean daily working capital requirement for the sample of vendors was in range of Rs. $250-500$

- The daily turnover for $88 \%$ of the sample was up to Rs. 300 while for the remaining sample it was up to Rs.500

- Profit per day was between Rs.100-250 for $48 \%$ of the vendors and between rs $250-500$ for $30 \%$ of the vendors

- Almost all the vendors re-invested their earnings on a daily basis (Rs.200-300) in purchasing next day stock

- House hold expenses constituted up to Rs.100 for $76 \%$ of the sample and up to Rs.200 for $26 \%$ of the sample

- $88 \%$ of the sample could not create savings from their meagre earnings

- None of the street vendors in the study sample had membership to any vendor organizations. They had no awareness of the existence of such organizations. However this study finding shows that the efforts were not sufficient and consistent. During the campaign NASVI recommended that the Tamilnadu government pass a government order for implementing the National Policy for Urban Street vendors as has been done in states like Delhi, Orissa, Madya Pradesh, Pondicherry, Rajasthan, Uttar Pradesh, Maharashtra and Jharkhand

- $80 \%$ of the street vendors in the sample had no awareness of the concept of micro finance and how it may be utilized to improve their access to financial resources. The national Policy on Urban Street Vendors 2009 recognized that absence of collateral and firm domiciliary status debars vendors from accessing institutional credit. The policy recommended that state governments and municipalities bring together Self-Help Groups (SHGs) and street vendor organizations and access credit from banks through the SHGBank linkage (National Policy for Urban Street Vendors, 2009). This study finding shows a failure of policy implementation

- Almost $99 \%$ of the street vendors in the sample were disinclined to formalize their bsiness. A similar finding was reported by a study of street vendors in Philippines city of Cebu (Destombes, 2010). According to the revision, the street vendor's goals were not positioned in the area of entering the official sector. Instead they only wished to expand their business in the existing framework.

\subsection{Comparison between Street Vendors' access to finance in Tirunelveli and Nagercoil Towns}

- Chi Square test showed significant difference between vendors in Tirunelveli and Nagercoil towns with respect to their stock purchase methods. While Tirunelveli vendors opted almost equally for cash and credit methods Nagercoil vendors opted for credit methods

- Chi Square test showed significant difference between Tirunelveli and Nagercoil town with respect to their sources of investment. While Tirunelveli vendors sought investment through money lenders, their own parents or spouse, Nagercoil vendors sought investment through their own savings 
International Journal of Managing Public Sector Information and Communication Technologies (IJMPICT), Vol. 6, No. 4, December 2015

\begin{tabular}{|l|l|}
\hline Variable & Pearson 'r' \\
\hline Sources of Investment & $12.92^{* *}$ \\
\hline Stock purchase methods & $10.72^{* *}$ \\
\hline
\end{tabular}

$* * \mathrm{p}<0.01$

\section{RECOMMENDATIONS}

This study finding revealed that street vendors in Tirunelveli and Nagercoil operate in severely dysfunctional circumstances. They lacked not only credible financial resources but also social capital. Co-operation between the vendors and instigation of vendor movements must be intensified to enable their voices to be heard at the policy level. NASVI's efforts require greater visibility and broader scope so as to reach the individual vendor operating in every urban street in the country.

Street vendors being a division of the unorganized sector have modest or no right to use credit from the official sector particularly for their economic activities without which they will have to depend on private moneylenders borrowing at high interest rates. The need of the hour is to implement and enforce national policies at the state level. Subsequently banks may be encouraged to extend credit to SHGs of vendors and also the vendors' Associations should be assisted by NGOs to create a financial interface between the vendors and official sector to access larger credit facilities.

\section{CONCLUSIONS}

The current study was an explorative and analytical survey of street vendors in Tiruneveli and Nagercoil towns in relation to their access to sources of finance. The lack of official information on the status of street vendors specifically in southern parts of Tamilnadu served as basis for this research survey. While several states have implemented the National Policy on Urban Street Vendors 2009; Tamilnadu is yet to take any steps in that direction. Using proportionate convenience sampling method, a sample of 50 street vendors, was selected from Tirunelveli and Nagercoil towns and administered a comprehensive questionnaire. Findings showed that the vendors faced severe constraints in securing funds for starting as well as operating their micro level business. The vendors also lacked social capital which is crucial entrepreneurial element for success. Additionally the study found differences between the circumstances of access to fund sources between Tirunelveli and Nagercoil Street vendors. The researchers recommend implementation of the national policy on street vendors at the state level, broadened scope of NASVI's activities and networking of bank and SHGs and street vendors to enable access to credible financial resources. 
International Journal of Managing Public Sector Information and Communication Technologies (IJMPICT), Vol. 6, No. 4, December 2015

\section{REFERENCES}

Bandla V.S (2013, Feb 27) “Thozhilalar Koodam: The Street Vendors' Bill - Effective or Ornamental? " Retrieved from tnlabour.in: http://tnlabour.in/?tag=street-vendors

[2] Bhowmik S.K and Debdulal S (2012) "Street Vending in Ten Cities in India: National Association of Street Vendors in India" Retrieved March 2013

[3] Destombes T (2010) "Informal Entrepreneurs: Street vendors, their livelihoods and the influence of social capital", Master thesis in International Development Studies, Cebu

[4] Sekar H.R (2008), "Vulnerabilities and Insecurities of the Informal Sector Workers: A Study of Street Vendors", Noida: V. V. Giri National labour Institute

[5] Srinivasan R (2012, June 20), The Chennai Kaleidoscope, Retrieved from http://www.transparentchennai.com/2012/06/20/street-vendors-field-work/

[6] The Hindu (2010) "Implement Policy for Urban Street Vendors, Trichy

[7] National Commission for Enterprises in the unorganised sector, Government of India, (2008) "Report on Conditions of Work promotion of Livelihoods in the Unorganised Sector", New Delhi: Academic Foundation

[8] National Policy for Urban Street Vendors (2009), Retrieved from http://mhupa.gov.in/policies/natpol.htm

[9] Soofi M.A (2012, Nov 02), Livemint and The Wall Street Journal, Retrieved from http://www.livemint.com/Leisure/NN6NKSWIU0wsojynMwFBBJ/Street-Vendors--The-God-ofsmall- sellers.html

\section{Author}

A. Mohamed Syed Ali received his B.E degree in Electrical and Electronics Engineering from KNSK College of Engineering, Nagercoil Under Anna University of Technology, Tirunelveli, TamilNadu, India in 2011. He was completed his M.Tech[CIT] degree in the specialization of Electronics Engineering from Manonmaniam Sundaranar University, Tirunelveli, Tamilnadu, India in 2014. He is presently working as Associate Research Analyst in NASDAQ OMX Corporate Solutions (India) Pvt. Ltd, Nagercoil, Tamilnadu, India and also pursuing Master of Business Administration (MBA)

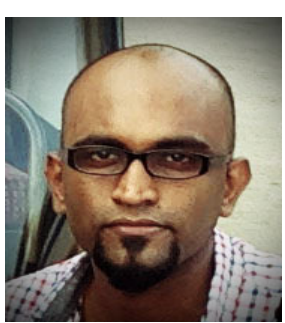
in Project Management. He has already attended several conferences in the field of Solar Energy, Energy conservation in buildings, Cogeneration, Medical Image Processing, Mobile Networking and published many papers in international journals and conference proceedings. His area of interest includes Energy conservation, Renewable Energy, Power Electronics, Medical Image Processing, Networking, Mobile Communication, Financial management and Investment Management. He is the member of Solar Energy Society of India (SESI), New Delhi and Energy and Fuel Users'Association of India (ENFUSE), Chennai and Cosmic Journals

Mrs.A.R. Sindhu is currently a Research Scholar in the Department of Management Studies, M. S University, Tirunelveli. She was the Head of the Department, MBA at James College of Engineering and Technology, Nagercoil, Tamilnadu from 2013 to 2014. She worked as Process Associate in a MNC in Chennai. She received her MBA in Finance \& Marketing from Anna University, Chennai and M.Phil in Management from Vinayaga Mission University, Salem. She had handled subjects like Financial Management, Financial Derivatives, Investment \& Portfolio Management, Fundamentals of Management and Organizational Behavior. She has guided several MBA students in their Project work and also attended various Conferences and Workshops of National/International repute. 
International Journal of Managing Public Sector Information and Communication Technologies (IJMPICT), Vol. 6, No. 4, December 2015

Vijaya Somasundaram holds a PhD (Psychology \& Criminology) from Manonmaniam Sundaranar University, Tirunelveli, India. She was qualified as a teaching professional in business management under the UGC-NET ( University Grants Commission - National Eligibility Test for lectureship) with MBA and MPhil degrees in Management from Madurai Kamaraj University. Additionally she has completed an MSc in Psychology from Mother Teresa Women's University and a PG Diploma in Victimology and Victim Assistance. She has worked as lecturer for a year in the Management Department of Infant Jesus College of Engineering, Tuticorin and two years as temporary lecturer in the Department of Management Studies of Manonmaniam Sundaranar University, Tirunelveli. She is presently working as Assistant Professor, Department of Management Studies, Rajalakshmi Engineering College, Chennai, India. She has several publications to her credit both national and international. She has travelled widely in India and abroad. She has co-presented a workshop on Creating Safe Spaces for Women at the International Women's Summit at Zurich, Switzerland and a paper on Domestic Violence at the International Symposium of the World Society of Victimology at Hague, Netherlands. She has been invited to talk at various seminars and workshops in academic and NGO institutions in Tirunelveli. She is part of a three member Indian team working under on the UK-India Education Research Initiative (UKIERI) project (Child rights along the journey from victim to survivor - child victims of sexual offences and criminal justice). 